\title{
PRZEDSIĘBIORCZOŚĆ AKADEMICKA W KLASTRACH WYSOKICH TECHNOLOGII JAKO PRZEJAW INTELIGENTNEJ SPECJALIZACJI ${ }^{2}$
}

\begin{abstract}
Przedmiotem artykułu o charakterze poznawczo-syntetyzującym są współczesne zagadnienia związane $\mathrm{z}$ rozwojem przedsiębiorczości akademickiej w klastrach wysokich technologii, których działalność spójna jest z głównymi założeniami koncepcji inteligentnej specjalizacji. Podjęte w nim rozważania naukowe i formułowane wnioski oparto na analizie literatury przedmiotu i danych zastanych (metoda desk research). Praktyczne podejście do charakteryzowanych zagadnień poparto licznymi przykładami z zakresu klasteringu w Polsce.

Artykuł składa się z czterech części. Przedstawiono w nich w sposób syntetyczny specyfikę inteligentnej specjalizacji, strategiczny wymiar klastrów wysokich technologii i przedsiębiorczości akademickiej, główne założenia koncepcji inteligentnego miasta i regionu uczącego się. Ponieważ koncepcja inteligentnej specjalizacji odnosi się do tożsamości regionu i sprawnego wykorzystania jego potencjału naukowego, technologicznego, społecznego i ekonomicznego, tym samym podjęto próbę wykazania, że związana jest ona pojęciowo z aktywnością klastrów wysokich technologii, przedsiębiorczością akademicką oraz kształtowaniem inteligentnych miast i regionów uczących się. Klastry wysokich technologii ujmowane jako organizacje inteligentne, tworzą ekosystem przyjazny dla rozwoju przedsiębiorczości akademickiej oraz inteligentnych miast i regionów uczących się. Sprzyja on przeciwdziałaniu barierom przedsiębiorczości, przyśpieszeniu komercjalizacji efektów badań naukowych, optymalnemu wykorzystaniu potencjału strategicznego współpracujących ze sobą firm wysokich technologii i uczelni wyższych o profilu technicznym oraz transferowi szeroko rozumianej wiedzy. Zakres i jakość oferowanego w ekosystemie klastra wsparcia dla technostarterów, w osiąganiu przez nich dojrzałości biznesowej, kształtuje wizerunek klastra.
\end{abstract}

Słowa kluczowe: klaster, technologia, przedsiębiorczość akademicka, inteligentna specjalizacja

\section{WSTĘP}

W obliczu istniejących wyzwań politycznych, społeczno-gospodarczych i technologicznych niejednokrotnie podkreśla się, że przedsiębiorczość i innowacyjność klastrów

\footnotetext{
${ }^{1}$ Dr Bogusław Bembenek, Katedra Przedsiębiorczości, Zarządzania i Ekoinnowacyjności, Wydział Zarządzania, Politechnika Rzeszowska im. Ignacego Łukasiewicza, Al. Powstańców Warszawy 8, 35-959 Rzeszów; e-mail: bogdanb@ prz.edu.pl

2 Artykuł powstał w ramach projektu naukowego „Synteza autonomicznego identyfikatora półpasywnego, dedykowanego do pracy w wielokrotnych, dynamicznych systemach RFID” (NCBR PBS1/A3/3/2012).
} 
wysokich technologii ma strategiczne znaczenie dla długofalowego procesu przemian zachodzących w gospodarce opartej na wiedzy oraz wzmacniania spójności gospodarczej, społecznej i terytorialnej. Według Komisji Europejskiej zmniejszenie dysproporcji w poziomach rozwoju regionów Unii Europejskiej, wprowadzenie gospodarki europejskiej, w tym poszczególnych gospodarek krajów członkowskich na ścieżkę wzrostu opartego na wiedzy i innowacjach, osiągnięcie właściwego poziomu postępu technologicznego i społeczno-gospodarczego, wymaga sprawnego wykorzystania potencjału sektora $\mathrm{B}+\mathrm{R}$ i ekosystemu, jaki zapewniają aktywnie działające klastry wysokich technologii. Jednakże, aby klastry te mogły w sposób dynamiczny rozwijać się, potrzebują stałego zasilania zasobami materialnymi i niematerialnymi. W tym przypadku niezwykle pomocne są efekty przedsiębiorczości akademickiej. Nowo powstające firmy pracowników uczelni, a także studentów i absolwentów, które w różnym stopniu wykorzystują wiedzę i technologie uczelni mogą wzmocnić dotychczasowy klastrowy łańcuch wartości lub kreować cenne dla klastra nowe relacje i łańcuchy dostaw w przestrzeni krajowej i międzynarodowej.

Celem artykułu jest charakterystyka możliwości i perspektyw rozwoju przedsiębiorczości akademickiej w środowisku klastrów wysokich technologii w kontekście koncepcji inteligentnej specjalizacji. $\mathrm{W}$ ramach tak określonego celu poszukiwano odpowiedzi na cztery pytania badawcze:

- w czym przejawia się strategiczny wymiar inteligentnej specjalizacji, klastrów wysokich technologii i przedsiębiorczości akademickiej?

- czy istnieje związek pojęciowy pomiędzy koncepcjami inteligentnej specjalizacji, przedsiębiorczości akademickiej, klastrów wysokich technologii, inteligentnych miast i regionów uczących się?

- czy aktywność polskich klastrów wysokich technologii spójna jest z inteligentnymi specjalizacjami w ich regionach zakorzenienia?

- czy istnieją dobre przykłady rozwoju przedsiębiorczości akademickiej w klastrach wysokich technologii w Polsce?

W artykule podjęto próbę przedstawienia kluczowych zagadnień i dominujących poglądów bezpośrednio związanych z problemem badawczym, będących odpowiedzią na istniejące wyzwania w gospodarce opartej na wiedzy. Rozważania naukowe prowadzono w oparciu o wybrane wyniki badań, uzyskane w procesie analizy literatury przedmiotu i danych zastanych (metoda desk research). W badaniach własnych cennymi źródłami informacji wtórnych były głównie strony internetowe klastrów i ich członków oraz raport badawczy z pogłębionej inwentaryzacji klastrów w Polsce, opracowany przez Polską Agencję Rozwoju Przedsiębiorczości (PARP).

Podstawową przesłanką wyboru tematu artykułu i określenia jego zakresu jest fakt, że przedsiębiorczość akademicka w klastrach wysokich technologii stanowi wciąż nowy obszar badań w Polsce i słabo ugruntowany w literaturze naukowej. Co prawda, bardzo popularny jest trend badań indywidualnie traktowanej przedsiębiorczości akademickiej i klastrów, jednakże stosunkowo rzadko w dotychczasowych badaniach uwzględniania była kwestia rozwoju tej formy przedsiębiorczości w klastrach wysokich technologii. Artykuł o charakterze przeglądowym ma tym samym przyczynić się do wypełnienia istniejącej luki wiedzy oraz stymulować twórczą i merytoryczną dyskusję w kontekście dynamicznego zarządzania klastrem, polityki klastrowej oraz budowy innowacyjnej i konkurencyjnej polskiej gospodarki. 


\section{SPECYFIKA INTELIGENTNEJ SPECJALIZACJI}

Koncepcja inteligentnej specjalizacji (smart specialisation) stanowi integralny element polityki Unii Europejskiej (UE) wobec regionów, będąc swoistym stymulatorem rozwoju gospodarczego. Powstała na początku XXI wieku na fundamencie regionalnych strategii innowacji, przez co potocznie określana jest strategią innowacji trzeciej generacji (RIS3) i elementem unijnej strategii Europa 2020. Komisja Europejska, aby zachęcić do efektywnego jej wdrażania, uczyniła ją kryterium decydującym o możliwości finansowania inwestycji ze środków UE w perspektywie 2014-2020, w których główną rolę odgrywają innowacje i nowe technologie ${ }^{3}$.

Zasadniczym celem inteligentnej (mądrej) specjalizacji, będącej elementem polityki gospodarczej Polski i Unii Europejskiej, jest szybszy rozwój gospodarki opartej na wiedzy i społeczeństwa informacyjnego, wzrost konkurencyjności krajów i regionów Unii Europejskiej, optymalne wykorzystanie różnorodności ich indywidualnego potencjału poprzez precyzyjne określenie i uwzględnienie ich tożsamości i uwarunkowań społecznych, gospodarczych i technologicznych w systemie edukacji. Ponadto za ważne uznano wzmocnienie sektora $\mathrm{B}+\mathrm{R}$ i jego potencjału innowacyjnego oraz rozprzestrzenianie technologii ogólnego zastosowania dzięki jej wykorzystywaniu w wyrobach i usługach. Osiągnięcie względnie trwałej przewagi konkurencyjnej na arenie międzynarodowej, w oparciu o lokalny i regionalny kapitał intelektualny, wymaga przede wszystkim ${ }^{4}$ :

- ciągłego kształtowania kapitału ludzkiego,

- sprawnego wykorzystania wiedzy oraz wyspecjalizowanej działalności B+R, dopasowanej do cech społeczno-gospodarczych konkretnego regionu,

- określenia priorytetów inwestycyjnych w obszarach specjalizacji,

- integrowania potrzeb biznesu $\mathrm{z}$ potencjałem podmiotów sektora $\mathrm{B}+\mathrm{R}$,

- pozyskiwania inwestorów krajowych i zagranicznych,

- rozwijania potencjału klastrów i tworzenia przestrzeni dla zróżnicowanych powiązań międzysektorowych i sieci ponadregionalnych,

- identyfikowania nisz rynkowych i nowych dziedzin biznesu,

- włączania w procesy innowacyjne użytkowników innowacji,

- wspierania dynamicznego rozwoju innowacji technologicznych,

- kreowania gospodarki zrównoważonej, efektywnie wykorzystującej zasoby, przyczyniającej się do włączenia społecznego i spójności terytorialnej.

Te i inne wdrażane w regionach działania w różnych obszarach są przejawem współczesnego paradygmatu rozwoju regionalnego i innowacji, a także sieciowania, partycypa-

${ }^{3}$ S. Godlewska, Strategie na rzecz inteligentnej specjalizacji (RIS3) - instrument realizacji polityki rozwoju vs. Warunek pozyskiwania funduszy unijnych, „Przegląd Europejski” 2013, nr 4 (30), s. 78. Z uwagi na to, że koncepcja inteligentnych specjalizacji regionalnych wynika z połączenia polityki sektorowej $\mathrm{z}$ regionalną to często określana jest nowym paradygmatem rozwoju regionalnego skoncentrowanego terytorialnie, trzecią generacją systemów innowacji oraz narzędziem kształtowania konkurencyjności i innowacyjności regionu. Por. E. Szostak, Inteligentne specjalizacje w rozwoju regionu, „Studia Ekonomiczne” 2015, nr 209, s. 216.

${ }^{4} \mathrm{M}$. Słodowa-Hełpa, Inteligentna specjalizacja polskich regionów: warunki, wyzwania i dylematy, „Roczniki Nauk Społecznych” 2013, t. 5 (41), nr 1, s. 92-93; A. Grądziel, Strategia inteligentnej specjalizacji stymulatorem rozwoju gospodarczego regionów, „Studia i Prace Wydziału Nauk Ekonomicznych i Zarządzania" 2014, nr 37, t. 2, s. 251. 
cji społecznej, myślenia i działania strategicznego kluczowych interesariuszy (m.in. władz samorządowych, podmiotów sektora B+R, przedsiębiorców), którzy mają realny i znaczący wpływ na kształtowanie konkurencyjności i innowacyjności regionu. Działania te powinny przyczynić się do doskonalenia zarówno działalności $B+R$ i innowacyjnej, jak i pomocy publicznej dla najbardziej perspektywicznych sektorów gospodarki.

Proces kształtowania inteligentnych specjalizacji w Polsce był oparty na kreatywności i przedsiębiorczym odkrywaniu, tak aby nie sprowadzał się jedynie do podjęcia arbitralnej decyzji administracji publicznej. Był to proces długotrwały i wieloetapowy, angażujący różnych interesariuszy procesu innowacyjnego. Należy podkreślić, że w wielu województwach kraju ten proces jest nadal kontynuowany $\mathrm{z}$ wykorzystaniem nowych metod i technik, nowych paradygmatów i nowych narzędzi typu platformy crowdsourcingowe, które w różnym stopniu wykorzystują tzw. mądrość tłumu ${ }^{5}$.

Inteligentne specjalizacje regionalne mocno związane są z klasteringiem. Tym samym w wielu regionach aktywnie działające klastry były źródłem identyfikacji kluczowych specjalizacji. Przyjęto bowiem, że klastry będą użytecznym narzędziem regionalnej strategii inteligentnej specjalizacji, pomagającym władzom samorządowym oddziaływać na rozwój regionalny oparty na innowacjach. Takie podejście było spójne z głównymi zaleceniami Komisji Europejskiej, które promowały klastry jako narzędzie służące nie tylko definiowaniu inteligentnych specjalizacji, ale także ich rozwijaniu. Niejednokrotnie na szczeblu europejskim podkreślano, że dobra strategia inteligentnej specjalizacji będzie stymulowała zmiany strukturalne i rozwój klastrów, co pozwoli na sprawne wykorzystanie korzyści wynikających $\mathrm{z}$ przestrzennej koncentracji działalności biznesowej i $\mathrm{B}+\mathrm{R}$ oraz z procesów produkcji i transferu wiedzy ${ }^{6}$. Doświadczenia dynamicznych klastrów potwierdziły tezę, że są one zorientowane na doskonalenie, rozwijają się w kierunku nowoczesnej polityki przemysłowej, wzmacniają konkurencyjność regionalnej gospodarki, przyśpieszają modernizację tradycyjnych sektorów gospodarki poprzez innowacje i sprzyjają powstawaniu nowych wyrobów i usług, procesów, metod, dzięki którym członkowie klastrów są bardziej konkurencyjni w przestrzeni krajowej i międzynarodowej ${ }^{7}$.

Przykładem klastra zaawansowanego technologicznie, wpisującego się w założenia inteligentnej specjalizacji jest Dolina Lotnicza. Z uwagi na dynamiczny rozwój regionalnego przemysłu lotniczego, skoncentrowanego w Dolinie Lotniczej, to właśnie lotnictwo i kosmonautykę uznano za wiodącą inteligentną specjalizację województwa podkarpackiego. Decyzja ta ma swe ekonomiczne, ekologiczne i społeczne uzasadnienie. Dotychczasowe doświadczenia Doliny Lotniczej potwierdzają tezę, że przedsiębiorcze klastry funkcjonują w obszarach inteligentnych specjalizacji, adekwatnych do specyfiki danego regionu. Cele strategiczne Doliny Lotniczej dotyczą przede wszystkim rozwoju klastrowego łańcucha dostaw, rozwoju sektora $\mathrm{B}+\mathrm{R}$ działającego na rzecz przemysłu lotniczego oraz wzmocnienia roli województwa podkarpackiego jako jednego z wiodących w Euro-

\footnotetext{
${ }^{5}$ S. Dziedzic, L. Woźniak, P. Czerepiuk, Proces przedsiębiorczego odkrywania jako metoda strategicznego planowania i implementacji inteligentnych specjalizacji regionu, „Prace Naukowe Uniwersytetu Ekonomicznego we Wrocławiu” 2016, nr 444, s. 110-111.

${ }^{6} \mathrm{M}$. Dzierżanowski, Definiowanie i rozwijanie inteligentnych specjalizacji - wnioski z dobrych praktyk w zakresie polityk klastrowych, Gdańsk 2013, s. 9.

7 A. Mempel-Śnieżyk, Koncepcje rozwoju regionalnego ze szczególnym uwzględnieniem klastrów i inteligentnych specjalizacji, „Biblioteka Regionalisty” 2013, nr 13, s. 116.
} 
pie regionów przemysłu lotniczego ${ }^{8}$. Wspólne działania marketingowe koordynatora i członków Doliny Lotniczej, współpraca z samorządami i uczelniami sprzyja generowaniu efektu synergii, który przejawia się w redukcji kosztów, sieciowaniu, jakości kapitału ludzkiego i relacyjnego. Wartością dodaną współpracy z władzami samorządowymi jest m.in. rozbudowa infrastruktury $\mathrm{B}+\mathrm{R}$ firm i uczelni oraz zmiana sposobu i obszarów kształcenia zawodowego w ekosystemie klastra. Członkowie klastra realizują projekty o różnym stopniu zaawansowania technologicznego ze swymi partnerami w ramach m.in. Centrum Zaawansowanych Technologii Areonet - Dolina Lotnicza i Polskiej Platformy Technologicznej Lotnictwa. Przedsiębiorczy koordynator klastra, tj. Stowarzyszenie Grupy Przedsiębiorców Przemysłu Lotniczego „Dolina Lotnicza”, już od przeszło 15 lat podejmuje liczne działania na rzecz sieciowania klastra w wymiarze krajowym i międzynarodowym. W ten sposób podjęto współpracę m.in. w ramach sieci European Aerospace Cluster Partnership (EACP), czy z klastrem „Kraina Podkarpacie”, działającym na rzecz jakości życia i zrównoważonego rozwoju regionu Podkarpacia. Współpraca firm przemysłu lotniczego z Wydziałem Budowy Maszyn i Lotnictwa Politechniki Rzeszowskiej, a także z sektorami powiązanymi, tj. sektorem informacyjno-komunikacyjnym, sektorem odlewniczym, sektorem elektromaszynowym w regionie zakorzenienia Doliny Lotniczej to mocny fundament rozwoju wysokich technologii, w tym kluczowych technologii wspomagających. Z uwagi na wyróżniającą się aktywność Doliny Lotniczej, niejednokrotnie porównuje się ją z najlepszymi klastrami lotniczymi we Francji i Kanadzie Aerospace Valley i Aero Montreal. W procesie przedsiębiorczego odkrywania inteligentnych specjalizacji w województwie podkarpackim, doceniając rolę regionalnego przemysłu lotniczego w kształtowaniu sektora wysokich technologii, uznano za celowe wzmocnienie rozwoju lotnictwa i kosmonautyki jako wiodącej inteligentnej specjalizacji, aby zbliżyć się do światowych wzorców ${ }^{9}$.

\section{STRATEGICZNY WYMIAR KLASTRÓW WYSOKICH TECHNOLOGII}

Klastry wysokich technologii, podobne w mniejszym lub większym stopniu do Doliny Krzemowej, są przedmiotem dużego zainteresowania naukowców, polityków i przedsiębiorców. Wynika to z tego, że sukces Doliny Krzemowej przejawiający się w dynamicznym rozwoju wysokich technologii (głównie ICT), innowacyjnych firm technologicznych i startupów, dobitnie pokazuje, jak można sprawnie budować kapitał intelektualny w ekosystemie klastra zaawansowanego technologicznie. Tym samym tego typu klastrom przypisuje się strategiczną rolę w kształtowaniu przedsiębiorczości, innowacyjności i konkurencyjności polskiej i europejskiej gospodarki. W ich ekosystemie szereg mechanizmów, m.in. dostęp do kapitału, wiedza o najnowszych technologiach i rynkach oraz zaangażowanie partnerów na rzecz realizacji wspólnych celów sprzyja rozwojowi ${ }^{10}$.

W literaturze przedmiotu klastry wysokich technologii określa się często mianem zaawansowanych technologicznie, opartych na wiedzy, innowacyjnych i badawczych. Tę

\footnotetext{
${ }^{8}$ http://www.dolinalotnicza.pl (dostęp: 1.09.2017 r.).

9 Regionalna Strategia Innowacji Województwa Podkarpackiego na lata 2014-2020 na rzecz inteligentnej specjalizacji (RIS3), Urząd Marszałkowski Województwa Podkarpackiego, Rzeszów 2016, s. 34-36.

${ }_{10}$ T. Bresnahan, A. Gambardella, Building high-tech clusters: Silicon Valley and beyond, Cambridge 2004, s. 1.
} 
grupę klastrów definiuje się jako skupiska firm działających w sektorze zaawansowanych technologii, podmiotów sektora $\mathrm{B}+\mathrm{R}$ i innych podmiotów z powiązanych branż, które charakteryzują się wysoką konkurencyjnością i intensywnymi interakcjami w obszarze pozyskiwania, wykorzystywania i rozwoju szeroko rozumianej wiedzy ${ }^{11}$. Tworza je skoncentrowane geograficznie przedsiębiorstwa i inne organizacje powiązane łańcuchem wartości dodanej, zorientowane na wysokie technologie i rozwój wiedzy, utrzymujące ścisłe relacje $\mathrm{z}$ różnymi podmiotami sektora $\mathrm{B}+\mathrm{R}$ (centrami wiedzy, ośrodkami naukowo-badawczymi, parkami naukowo-technologicznymi) ${ }^{12}$. Relacje formalne i nieformalne członków klastrów rozwijają się wokół prowadzenia zaawansowanych projektów badawczych, projektowania nowych technologii oraz zarządzania wiedzą.

Funkcjonujące w teorii i praktyce gospodarczej różne definicje sektora wysokich technologii potwierdzają, że sektor ten charakteryzuje się ${ }^{13}$ :

- wysoką innowacyjnością, przedsiębiorczością i elastycznością,

- uzależnieniem od kapitału intelektualnego,

- wysokim poziomem zatrudnienia pracowników $\mathrm{z}$ wyższym wykształceniem,

- aktywną współpracą firm wysokich technologii z podmiotami sektora $\mathrm{B}+\mathrm{R}$ oraz $\mathrm{z}$ firmami świadczącymi usługi wiedzochłonne,

- intensywnością prac B+R i wysokim udziałem wydatków na B+R,

- szerokim wykorzystaniem zaawansowanych technologii, które podlegają relatywnie „,szybkiemu starzeniu się”,

- krótkim cyklem życia inwestycji, wyrobów i technologii,

- szybką dyfuzją innowacji,

- wysokim ryzykiem inwestycyjnym,

- dużymi nakładami kapitałowymi i problemami z pozyskaniem finansowania,

- dużą skłonnością do internacjonalizacji działalności.

Głównymi członkami klastrów wysokich technologii są przedsiębiorstwa zaawansowane technologicznie. Są to podmioty wysoce innowacyjne i przedsiębiorcze, które rozwijają, produkują i sprzedają dobra i usługi wiedzochłonne, wykorzystujące współczesny dorobek nauki i techniki ${ }^{14}$. Do tej grupy zaliczyć można producentów materiałów i wyrobów lotniczych, farmaceutycznych, elektronicznych, optycznych, energetycznych, komputerowych. Wyroby sektora wysokich technologii powstają w oparciu o nanotechnologie i biotechnologie, a także technologie informacyjne, chemiczne, energetyczne i kosmicz$n \mathrm{e}^{15}$. Jednakże nie zamyka to pełnej listy przedsiębiorstw tego typu klastra. Wciąż nie

11 A. Baranowska, J. Gąska, M. Lis, D. Pelle, Ł. Skrok, Klastry zaawansowanych technologii jako instrument wsparcia rozwoju i konkurencyjności regionów - analiza i wnioski dla polityki regionalnej oraz polityki spójności, Warszawa 2009, s. 9.

12 A. Zakrzewska-Bielawska, Relacje między strategia a struktura organizacyjna $w$ przedsiębiorstwach sektora wysokich technologii, Łódź 2011, s. 56.

13 A. Skórska, Sektor high-tech jako czynnik wzrostu konkurencyjności polskiej gospodarki w perspektywie 2020 roku, „Zarządzanie i Finanse” 2016, Vol. 14, nr 3, s. 240; M. Ratajczak-Mrozek, Specyfika przedsiębiorstw zaawansowanych technologii (high-tech), „Przegląd Organizacji” 2011, nr 2, s. 26-29.

14 A. Adamik, A. Zakrzewska-Bielawska, Rozwój przedsiębiorstw high-tech [w:] Koopetycja w rozwoju przedsiębiorstw high-tech, pod red. A. Zakrzewskiej-Bielawskiej, Warszawa 2014 , s. 16.

${ }^{15}$ M. Ratajczak-Mrozek, Specyfika przedsiębiorstw..., s. 27-28. 
sposób jest bowiem dokładnie określić granic i wielkości sektora wysokich technologii ze względu na brak jego jednoznacznej i powszechnie akceptowanej definicji.

Według A. Zakrzewskiej-Bielawskiej każde przedsiębiorstwo wysoko technologiczne jest przedsiębiorstwem innowacyjnym, organizacją opartą na wiedzy i uczącą się. Jednak nie każde przedsiębiorstwo innowacyjne, nie każda organizacja oparta na wiedzy i ucząca się jest przedsiębiorstwem zaawansowanym technologicznie. Tego typu przedsiębiorstwa zwykle działają na styku gospodarki i nauki, wykorzystują w szerokim zakresie technologie informacyjne, są otwarte na współpracę z otoczeniem, współtworząc różnego rodzaju powiązania sieciowe i klastry ${ }^{16}$. Realizując sprawnie koopetycję sieciową są w stanie optymalizować korzyści, które sprzyjają wzrostowi ich konkurencyjności. W związku z tym powinny podejmować współpracę z większą liczbą swych konkurentów i w różnych obszarach ich łańcucha wartości ${ }^{17}$. Ich proces internacjonalizacji przebiega znacznie szybciej niż przedsiębiorstw funkcjonujących w branżach tradycyjnych ${ }^{18}$. Ważnymi determinantami ich rozwoju są różne formy współpracy oraz tempo wprowadzania wyrobów i usług na szeroką, międzynarodową skalę ${ }^{19}$. Tym samym szersza współpraca $\mathrm{z}$ ich partnerami zagranicznymi m.in. w ramach międzynarodowych sieci, powiązań organizacyjnych i kapitałowych, może pomóc w sprawnym wykorzystaniu i wzmocnieniu potencjału klastrów zaawansowanych technologicznie.

Z badań A. Zakrzewskiej-Bielawskiej wynika, że w polskim sektorze wysokich technologii zdolność do współpracy w zakresie tworzenia nowych technologii w modelu otwartych innowacji oceniana jest na umiarkowanym poziomie. Im bardziej zróżnicowany jest potencjał relacyjny przedsiębiorstw wysokich technologii, tym zdolność ta jest wyższa, a poszczególne relacje charakteryzują się większym stopniem korzystności ${ }^{20}$. Wiele tych przedsiębiorstw dąży do przywództwa technologicznego i innowacyjnego, opracowując nowe technologie w oparciu o własne zaplecze $B+R$ i zewnętrzne źródła jej pozyskania z zachowaniem personalizacji w zarządzaniu wiedzą ${ }^{21}$.

Aktywność klastrów wysokich technologii jest po części efektem globalizacji, przekształceń przemysłu i jego struktury, interakcyjnego modelu innowacji i rozwoju gospodarki opartej na wiedzy. Szybkość ich rozwoju uzależniona jest od wielu czynników, w tym głównie od twórczości technologicznej, dynamiki dyfuzji i adaptacji innowacji technologicznych w gospodarce. Oczywiście proces ten zupełnie inaczej przebiega

${ }^{16}$ A. Zakrzewska-Bielawska, Relacje między strategia a struktura organizacyjna $w$ przedsiębiorstwach sektora wysokich technologii, Łódź 2011, s. 38-44.

17 A. Zakrzewska-Bielawska, Rola koopetycji w podnoszeniu konkurencyjności przedsiębiorstw benchmarki działań koopetycyjnych $w$ praktyce firm high-tech, „Prace Naukowe Uniwersytetu Ekonomicznego we Wrocławiu" 2014, nr 363, s. 84.

${ }^{18}$ N. Daszkiewicz, Internacjonalizacja przedsiębiorstw z branż high-tech, „Problemy Zarządzania” 2015, Vol. 13, nr 4 (56), s. 68.

${ }^{19}$ M. Ratajczak-Mrozek, Proces umiędzynarodowienia a wspótpraca przedsiębiorstw high-tech z podmiotami zagranicznymi, „Gospodarka Narodowa” 2013, nr 1-2, s. 54.

20 A. Zakrzewska-Bielawska, Potencjat relacyjny a innowacyjność przedsiębiorstwa $-w$ kierunku open innovation, „Management Forum” 2016, Vol. 4, nr 1, s. 8.

21 A. Zakrzewska-Bielawska, Strategie wzrostu przedsiębiorstw sektora wysokich technologii w ujęciu empirycznym, ,Prace Naukowe Uniwersytetu Ekonomicznego we Wrocławiu” 2011, nr 219, s. 310. 
w krajach rozwiniętych gospodarczo, niż w krajach rozwijających się. Szczególnie dobrą dynamikę rozwoju obserwuje się na rynkach wschodzących ${ }^{22}$.

Jednym z obszarów aktywności klastrów wysokich technologii są kluczowe technologie wspomagające (key enabling technologies), obejmujące mikro- i nanoelektronikę, materiały zaawansowane, biotechnologię przemysłową, fotonikę, nanotechnologię i zaawansowane systemy produkcji. Według Komisji Europejskiej celowe jest inwestowanie w tym obszarze, gdyż technologie te sprzyjają rozwojowi i wzrostowi unijnej gospodar$\mathrm{ki}^{23}$. J. Szmigiel uwzględniając specyfikę tych technologii, w tym ich multidyscyplinarny charakter, zidentyfikowała dwa typy klastrów ${ }^{24}$ :

- klastry różnej wielkości, często z koordynatorem w postaci podmiotu sektora $B+R$, skoncentrowane wokół konkretnej technologii wspomagającej, których głównym celem jest jej rozwijanie i promowanie zarówno wyników prac $B+R$, jak i samych technologii (np. klastry biotechnologiczne, fotoniczne, nanotechnologiczne),

- klastry skoncentrowane w ramach danej branży na rozwoju konkretnej technologii wspomagającej lub zespołu tych technologii, co pozwala na tworzenie innowacyjnych produktów, aktywne ich promowanie oraz osiąganie tą drogą przewagi konkurencyjnej (np. klaster samochodów elektrycznych).

Kluczowe technologie wspomagające w wielu regionach Polski są elementem inteligentnych specjalizacji z uwagi na ich multidyscyplinarny, horyzontalny i funkcjonalny charakter oraz potencjał transformacyjny. Sprzyjają one dynamicznemu powstawaniu innowacyjnych wyrobów, nowych przedsiębiorstw i branż. Jednakże istniejące bariery przedsiębiorczości i innowacyjności wciąż utrudniają optymalne wykorzystanie ich potencjału społeczno-gospodarczego ${ }^{25}$.

Efektywnie działające klastry zaawansowane technologicznie przyczyniają się do rozwoju kapitału intelektualnego i społecznego, w tym nowej wiedzy, wynalazków, patentów i innowacji. Tworzą naturalne środowisko sprzyjające konwergencji technologicznej m.in. przez ułatwienie przepływu i upowszechniania wiedzy. Jednocześnie konwergencja ta może przywrócić atrakcyjność dojrzałego lub schyłkowego klastra. Klastry specjalizujące się w kilku technologiach mają większą przewagę konkurencyjną w stosunku do klastrów, które specjalizują się w pojedynczych technologiach ${ }^{26}$.

W ramach ogólnopolskich badań Polskiej Agencji Rozwoju Przedsiębiorczości (PARP) w 2015 roku, mających na celu inwentaryzację klastrów w Polsce, zidentyfikowano 134 klastry działające i 106 klastrów potencjalnych, które nie spełniły wszystkich przyjętych w badaniach kryteriów (np. masa krytyczna, strategia rozwoju, komunikacja marketingowa, realizowane projekty, aktywność koordynatora), przez co nie można było

${ }^{22}$ P. Łasak, Rola rodzimych korporacji wielonarodowych $w$ rozwoju przemystu wysokich technologii na rynkach wschodzacych, ,Studia Ekonomiczne - Zeszyty Naukowe Uniwersytetu Ekonomicznego w Katowicach" 2016, nr 271, s. 103.

${ }^{23}$ http://www.pi.gov.pl (dostęp: 1.10.2017 r.).

${ }^{24}$ J. Szmigiel, Klastry jako instrument wsparcia sektora kluczowych technologii wspomagajacych, „Handel Wewnętrzny” 2016, nr 6 (365), s. 170.

25 A. Baran, Prawne aspekty innowacyjności w kontekście kluczowych technologii wspomagajacych, „Zeszyty Naukowe Politechniki Śląskiej. Organizacja i Zarządzanie” 2014, nr 71, s. 18-19.

${ }^{26}$ M. Runiewicz-Wardyn, Dynamika przemystów wysokich technologii a rozwój klastrów wiedzy na przyktadzie klastra Route 128, „Master of Business Administration” 2011, nr 4 (114), s. 53. 
uznać ich za klastry działające ${ }^{27}$. W okresie badań stwierdzono, że w klastrach działających 4578 firm stanowiło blisko 80\% ich członków ogółem. W tej grupie ilościowo przeważały mikrofirmy (47\%), zaś dużych firm było relatywnie niewiele (wykres 1). Taka sytuacja jest efektem tego, że polski sektor przedsiębiorstw jest zdominowany przez mikroprzedsiębiorstwa $(96 \%)^{28}$. Z kolei 513 podmiotów sektora B+R stanowiło blisko 9\% spośród 5868 wszystkich członków badanych klastrów. Podmioty te (uczelnie, instytuty badawcze, instytut PAN) w 13 klastrach pełniły funkcję koordynatora.

Spośród 134 działających klastrów - 36\% z nich reprezentowało klastry wysokich technologii (technologie informacyjno-komunikacyjne - ICT, przemysł metalowy, technologie produkcji, chemia i biotechnologia, lotnictwo, nanotechnologie, fotonika i optoelektronika). Najwięcej klastrów wysokotechnologicznych zidentyfikowano w województwach o wysokim poziomie innowacyjności - tj. śląskim i dolnośląskim, zaś znacznie mniej w świętokrzyskim. Z kolei w województwie warmińsko-mazurskim tego typu klastrów nie zidentyfikowano.

Z badań wynikało, że najbardziej popularną specjalizacją polskich klastrów wysokich technologii w okresie badań były technologie informacyjno-komunikacyjne (20 klastrów ICT), a najmniej popularną - lotnictwo (4 klastry), fotonika (2 klastry), biotechnologia (2) i nanotechnologia (1). Klastry ICT funkcjonowały w 11 z 16 województw kraju. W pięciu województwach, tj. opolskim, warmińsko-mazurskim, podlaskim, świętokrzyskim i małopolskim tej specjalizacji klastrów nie zidentyfikowano. Z kolei w kolejnych pięciu województwach zidentyfikowano więcej niż jeden klaster ICT. Dla przykładu w województwie śląskim - 5, lubelskim - 3, lubuskim, mazowieckim i wielkopolskim - po 2 klastry.

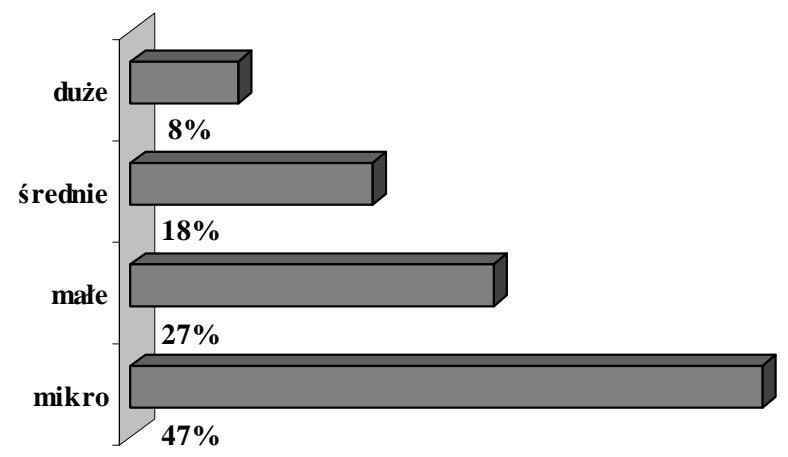

Wykres 1. Struktura biznesu w badanych klastrach według wielkości przedsiębiorstw $(\mathrm{N}=4578)$

Źródło: opracowanie własne na podstawie: G. Buczyńska, D. Frączek, P. Kryjom, Raport z inwentaryzacji..., s. 24.

${ }^{27}$ G. Buczyńska, D. Frączek, P. Kryjom, Raport z inwentaryzacji klastrów w Polsce - 2015, PARP, Warszawa 2016, s. 34-39, 55, 65-75.

${ }^{28} \mathrm{Na}$ przestrzeni ostatnich lat nastąpił dynamiczny wzrost liczby mikrofirm w Polsce. Firmy te, w porównaniu z pozostałymi grupami przedsiębiorstw, są najbardziej produktywne, efektywne kosztowo i rentowne. Większość z nich koncentruje się na rynku krajowym. Często po pierwszym roku ich działalności przeżywają średnio dwie trzecie z nich. Dane z ostatnich lat wskazują, że systematycznie poprawia się sytuacja mikroprzedsiębiorców. W strukturze tych firm wzrasta udział podmiotów najstarszych, działających na rynku 5 lub więcej lat. Por. PARP, Raport o stanie sektora matych $i$ średnich przedsiębiorstw w Polsce, PARP, Warszawa 2017, s. 10. 
Szeroko definiowany sektor informacyjno-komunikacyjny, który jest fundamentem rozwoju klastrów ICT w 11 województwach kraju uznano za inteligentną specjalizację, w różny sposób określoną, np. jako: rozwój oparty na ICT; technologie interaktywne w środowisku nasyconym informacyjnie; inteligentne systemy zarządzania; przetwarzanie informacji, multimedia, programowanie i usługi ICT; informatyka i telekomunikacja; technologie informacyjno-komunikacyjne.

Spośród 106 klastrów potencjalnych $-29 \%$ z nich reprezentowało sieci organizacyjne związane w różnym stopniu $\mathrm{z}$ przemysłem wysokich technologii. I w tym przypadku najbardziej popularną specjalizacją 13 zidentyfikowanych potencjalnych klastrów były technologie informacyjno-komunikacyjne. Z kolei najmniej popularną specjalizacją reprezentowaną przez trzy sieci organizacyjne były technologie kosmiczne i lotnicze.

\section{ROZWÓJ PRZEDSIĘBIORCZOŚCI AKADEMICKIEJ W KLASTRACH WYSOKICH TECHNOLOGII - PRÓBA SYNTEZY}

Udział środowiska akademickiego w klastrach wysokich technologii jest zarówno niezbędny, jak i korzystny. Podmioty z tego środowiska mogą pełnić rolę lidera w klastrze lub aktywnego członka klastra. Niezmiernie ważne jest zapewnienie przez uczelnie wysokiego poziomu badań naukowych oraz dydaktyki, w tym także aktywne nauczanie i promowanie przedsiębiorczości akademickiej, tworzenie odpowiedniego klimatu do transferu technologii, rozwoju spółek spin-off i start-upów, pozyskiwanie specjalistów z kraju i za granicy, wykorzystywanie innowacyjnej infrastruktury badawczej ${ }^{29}$. Podobnie uważają E. Skawińska i R. Zalewski stwierdzając, że zasadniczą determinantą rozwoju klastra wysokich technologii jest aktywność uczelni wyższej o profilu technicznym i innych ośrodków naukowych na jego terytorium zakorzenienia. Podmioty te kształtują podaż wysokiej jakości kapitału ludzkiego, co przekłada się na nowe pomysły, wyroby, usługi, technologie i przedsiębiorcze działania ${ }^{30}$.

Z punktu widzenia urzeczywistnienia ambitnych celów członków klastrów wysokich technologii szczególnie cennym dla nich partnerem są przedsiębiorcze uczelnie (tzw. uczelnie trzeciej generacji). Model uczelni przedsiębiorczej pojawił się w Europie pod koniec XX wieku. Zakłada potrzebę zmian w kulturze organizacyjnej uczelni i przyjęcia przez nią jako instytucji współtworzącej społeczeństwo i gospodarkę opartą na wiedzy, w coraz większym stopniu orientacji rynkowej, marketingowej, innowacyjnej, strategicznej, uwzględniającej społeczną odpowiedzialność. Oznacza to, że tego typu uczelnia buduje trwałe relacje $\mathrm{z}$ kluczowymi interesariuszami, badając ich oczekiwania i wymagania, będąc zorientowana rynkowo w działalności dydaktycznej i badawczej oraz profesjonalnie zarządzając swoim rozwojem ${ }^{31}$.

${ }^{29}$ K. Gurba, Rola uczelni wyższych w klastrach wysokich technologii, „Zarządzanie i Finanse” 2012, nr 1, s. 86.

${ }^{30}$ E. Skawińska, R. Zalewski, Klastry biznesowe w rozwoju konkurencyjności i innowacyjności regionów, Warszawa 2009, s. 179.

31 We współczesnym podejściu do uczelni wyższej coraz częściej podkreśla się jej znaczenie w procesie wytwarzania wiedzy, służącej rozwiązywaniu konkretnych problemów społecznych, ekonomicznych i przemysłowych. Uczelnia powinna wykazywać się cechami organizacji przedsiębiorczej, opartej na wiedzy, uczącej się i inteligentnej oraz społecznie odpowiedzialnej. Por. A. Piasecka, Przedsiębiorcza uczelnia jako wspótczesny model szkoty wyższej, „Zeszyty Naukowe Uniwersytetu Szczecińskiego” 2012, nr 725, „Ekonomiczne Problemy Usług”, nr 98, s. 163. 
W środowisku naukowym coraz częściej podejmuje się dyskuję o potrzebie przejścia z tradycyjnego modelu szkolnictwa wyższego do tego bardziej przedsiębiorczego. Poddając analizie to zagadnienie J. Olearnik i M. Pluta-Olearnik wykazują, że polskie uczelnie publiczne dotychczas nie wykazywały cech przedsiębiorczych w zadowalającym stopniu. Sytuacja ta znacznie lepiej przedstawia się w uczelniach prywatnych, działających według reguł rynkowych i kryteriów efektywności ekonomicznej. Słabe strony wielu uczelni to m.in.: ograniczoność i małe zdywersyfikowanie źródeł finansowania, niezadowalające wykorzystanie narzędzi marketingu, dominacja orientacji wewnętrznej nad zewnętrzną 32 .

Według Ł. Sułkowskiego i R. Seligi kształtowanie się uniwersytetu przedsiębiorczego i stopniowe wdrażanie koncepcji zarządzania strategicznego w uczelniach wyższych to efekt dokonujących się przekształceń społecznych, gospodarczych oraz kulturowych. Tendencja w kierunku rozwoju uniwersytetu przedsiębiorczego jest trwała, co znajduje swój wyraz w orientacji strategicznej zarówno na poziomie całej uczelni, jak i wybranych jej obszarów funkcjonalnych ${ }^{33}$.

Przykładem polskiej uczelni wyższej, która zmierza w kierunku modelu uczelni przedsiębiorczej jest Uniwersytet Śląski w Katowicach. Uczelnia kształci specjalistów w zakresie wielu nauk, w tym przyrodniczych, technicznych, ścisłych, humanistycznych i społecznych. Realizuje prace B+R w obszarach priorytetowych dla rozwoju polskiej i światowej gospodarki. Promuje przedsiębiorczość akademicką poprzez stymulowanie do tworzenia spółek spin-off i spin-out, aby w ten sposób przyśpieszyć transfer wiedzy naukowej i technologii do gospodarki. Firmy technologiczne pracowników uczelni sprzyjają rozwojowi procesu tworzenia innowacji i zacieśniają współpracę nauki z lokalną gospodarką. Efektem przedsiębiorczości akademickiej są m.in. takie spółki jak: abtowbiotechnology, k-12, Off-Science, Pracownia Dobrych Zmian ${ }^{34}$. Uniwersytet Śląski w Katowicach wraz z licznymi partnerami strategicznymi ze środowiska biznesu i otoczenia biznesu oraz władzami samorządowymi, dostrzegając potencjał regionu śląskiego w rozwoju nanotechnologii i dążąc do trwałego wzmocnienia jego pozycji konkurencyjnej na krajowym i europejskim rynku wysokich technologii, doprowadził do pomyślnego ukonstytuowania struktury Ślaskiego Klastra Nano w 2013 roku. Klaster ma na celu realizację wspólnych projektów $\mathrm{B}+\mathrm{R}$, efektywny transfer i komercjalizację wyników badań oraz wzmocnienie innowacyjności regionu. Członkowie klastra przyjęli, że klaster pozwoli na stworzenie wielopłaszczyznowej, trwałej platformy współpracy sprzyjającej efektywnemu połączeniu i wykorzystaniu ich potencjału na rzecz promocji i rozwoju nanotechnologii na Śląsku. Będzie on sprzyjał promocji działaności i osiagnięć członków klastra na arenie krajowej i międzynarodowej. Ponadto będzie stymulował liczne dyskusje kluczowych interesariuszy branży nanotechnologicznej, tak aby wypracować wspólne stanowiska w kwestiach ważnych dla tej branży i doprowadzić do ukształtowania właściwych warunków systemowych korzystnych dla rozwoju działalności badawczej i gospodarczej w dziedzinie nanotechnologii ${ }^{35}$.

\footnotetext{
32 J. Olearnik, M. Pluta-Olearnik, Uniwersytet przedsiębiorczy - herezja czy nowa orientacja na uczelni?, „Horyzonty Wychowania” 2016, Vol. 15, nr 35, s. 65-66.

${ }^{33}$ Ł. Sułkowski, R. Seliga, Przedsiębiorczy uniwersytet - zastosowanie zarzadzania strategicznego, „Prace Naukowe Uniwersytetu Ekonomicznego we Wrocławiu” 2016, nr 444, s. 486-487.

${ }^{34} \mathrm{http} / / / \mathrm{www}$. transfer.us.edu.pl/firmy-na-uniwersytecie-slaskim (dostęp: 1.11.2017 r).

$35 \mathrm{http} / / /$ nanoslask.pl/index.php/pl/inicjatorzy-klastra/uniwersytet-slaski (dostęp: 1.10.2017 r.).
} 
Kolejnego przykładu w analizowanym obszarze dostarcza Politechnika Rzeszowska. Pod koniec 2017 roku uczelnia została animatorem nowej inicjatywy klastrowej, która ma przyczynić się do urzeczywistnienia koncepcji przemysłu 4.0. Dzięki trwałej integracji środowiska akademickiego z przedsiębiorstwami, które produkują komponenty i systemy wykorzystywane $\mathrm{w}$ inteligentnych fabrykach i realizują prace $\mathrm{B}+\mathrm{R}$ z zakresu innowacji technologicznych, możliwe będzie wzmocnienie innowacyjności gospodarki. Politechnika Rzeszowska należy do grupy liderów w zakresie badań nad aplikacją przemysłową wspomaganych komputerowo systemów projektowania, prototypowania, wytwarzania i automatyzacji procesów produkcyjnych. Aktywność partnerów inicjatywy klastrowej w ramach przemysłu 4.0 jest spójna $\mathrm{z}$ inteligentną specjalizacją zarówno na poziomie województwa podkarpackiego, jak całego kraju ${ }^{36}$. Należy podkreślić, że poszczególne wydziały Politechniki Rzeszowskiej są zaangażowane we współpracę z biznesem w kilku klastrach, takich jak: Dolina Lotnicza, Klaster Spawalniczy Klastal, Klaster Przetwórstwa Tworzyw Sztucznych, Klaster Technologia w Medycynie ${ }^{37}$. Jej Centrum Transferu Technologii (CTT), będące ogólnouczelnianą jednostką organizacyjną, złożone jest z Biura Transferu Innowacyjnych Technologii (Dział ds. Ochrony Własności Intelektualnej i Dział Transferu Technologii) oraz Biura Badań i Projektów Naukowych Realizowanych z Podmiotami Gospodarczymi (Działy Projektów Krajowych i Międzynarodowych). Celami tej jednostki są m.in.: rozwój przedsiębiorczości akademickiej, stymulowanie i inicjowanie współpracy pomiędzy uczelnią a przedsiębiorcami, inicjowanie sieciowania przedsiębiorstw i podmiotów sektora $\mathrm{B}+\mathrm{R}$, zarządzanie własnością intelektualną uczelni, komercjalizacja bezpośrednia. Jednym $\mathrm{z}$ wielu projektów $\mathrm{B}+\mathrm{R}$ o dużym potencjale komercyjnym, zrealizowanych przez pracowników Politechniki Rzeszowskiej, jest projekt "Synteza autonomicznego identyfikatora półpasywnego, dedykowanego do pracy w wielokrotnych, dynamicznych systemach RFID”. Na realizację tego projektu w okresie 1.10.2012 r. - 30.09.2015 r. przeznaczono kwotę 5041396 zł z Narodowego Centrum Badań i Rozwoju. Pracownicy z Zakładu Systemów Elektronicznych i Telekomunikacyjnych, dostrzegając znaczący potencjał aplikacyjnego wykorzystania techniki RFID, podjęli się realizacji intensywnych prac $\mathrm{B}+\mathrm{R}$ celem projektowania innowacyjnych zmian w tym obszarze. Liczne wady dostępnych na rynku konstrukcji pasywnych, które podnoszą koszty ich eksploatacji stanowiły podstawę do opracowania innowacyjnej koncepcji bezbateryjnego demonstratora dla wielopasmowego, autonomicznego, półpasywnego identyfikatora RFID. Jego konstrukcja stwarza możliwość pozyskiwania zasilania z otoczenia, w tym np. z pola elektromagnetycznego systemów radiokomunikacyjnych powszechnego użytku i pomiaru wilgotności, temperatury, natężenia światła, ciśnienia. Wyniki tych pomiarów zapisywane są w wewnętrznej pamięci indentyfikatora RFID, dzięki czemu mogą znaleźć zastosowanie w doskonaleniu procesów logistycznych, magazynowania, transportowych i wytwórczych. Innowacyjność powstałego rozwiązania przejawia się nie tylko w wykorzystaniu superkondensatora zamiast baterii, który może magazynować relatywnie dużo energii, ale też w unikalnych możliwościach technicznych w zakresie automatycznej identyfikacji obiektów i niezawodności działania. Na rynku nie ma

\footnotetext{
${ }^{36}$ http://przemysl-40.pl/index.php/2017/10/14/w-rzeszowie-utworzono-klaster-industry-4-0/ (dostęp: 1.11.2017 r.).

37 https://przemysl.prz.edu.pl/klastry (dostęp: 1.12.2017 r.).
} 
identycznego rozwiązania technicznego ${ }^{38}$. Tym samym tego typu innowacja pozwala na kontynowanie prac B+R, których finalny efekt będzie można skomercjalizować. Naukowcy zakładają, że wraz z rozwojem techniki RFID z autonomicznym, półpasywnym identyfikatorem (RFID z API) nastąpi radykalny wzrost praktycznych jej zastosowań, przez co pojawią się nowe rynki i obszary życia społeczno-gospodarczego ${ }^{39}$.

Jednym z fundamentalnych komponentów koncepcji przedsiębiorczej uczelni jest przedsiębiorczość akademicka. Coraz liczniejsze dobre praktyki w tym obszarze świadczą o tym, że praktyczny wymiar przedsiębiorczości akademickiej przyśpiesza przejście $\mathrm{z}$ modelu tradycyjnego do modelu przedsiębiorczej uczelni ${ }^{40}$. Pojęcie przedsiębiorczości akademickiej, które związane jest z istotą przedsiębiorczości i transferem technologii, najczęściej definiowane jest jako ${ }^{41}$ :

- specyficzny rodzaj przedsiębiorczości, koncentrujący się na kreatywnych postawach i działaniach wewnętrznych interesariuszy uczelni wyższych, w tym sprawnym wykorzystaniu ich efektów pracy naukowej w praktyce gospodarczej,

- proces tworzenia przedsiębiorstw przez pracowników naukowych i studentów w ramach uczelni wyższych i poza nimi,

- proces tworzenia firm typu spin-off i spin-out przez pracowników naukowych, w różnym stopniu zaawansowanych technologicznie,

- zaangażowanie pracowników i studentów z danej uczelni w prowadzoną przez nich działalność gospodarczą,

- aktywne postawy członków środowiska akademickiego w celu komercjalizacji ich wiedzy i dorobku naukowego uczelni.

Przedstawione definicje przedsiębiorczości akademickiej wskazują na zachowania przedsiębiorcze technostarterów. Są nimi nauczyciele akademiccy, pracownicy inżynieryjno-techniczni i studenci, którzy prowadzą własną firmę technologiczną w różnym stopniu uzależnioną od ich macierzystej uczelni. Większe uzależnienie od uczelni może być efektem wykorzystywania jej know-how, technologii, infrastruktury $\mathrm{B}+\mathrm{R}$ w ramach prowadzonej działalności gospodarczej. Technostarterzy to osoby wykazujące się przedsiębiorczą inicjatywą, kreatywne, zafascynowane nowymi technologiami, odpowiedzialne, wytrwałe w dążeniu do celu, ambitnie podejmujące ryzyko. Często intuicyjnie dostrzegają potrzeby rynku. Ich pasja jest dla nich prawdziwą siłą napędową, pozwalającą przezwyciężać pojawiające się problemy ${ }^{42}$. Podobny zestaw zasadniczych cech technostarterów przedstawia K. Poznańska, podkreślając ich otwartość na współpracę z otoczeniem i koncentrację na ciągłym doskonaleniu ${ }^{43}$.

${ }^{38}$ B. Ziółkowski, T. Piecuch, M. Jankowska-Mihułowicz, K. Chudy-Laskowska, Rozwój systemów RFID w przedsiębiorstwach. Wyniki badań metoda delficka, Rzeszów 2016, s. 37-39.

${ }^{39}$ B. Ziółkowski, M. Jankowska-Mihułowicz, K. Chudy-Laskowska, T. Piecuch, Uwarunkowania konkurencyjności przedsiębiorstw stosujących systemy RFID z API - wyniki badań metoda delficka, ,Przegląd Nauk Ekonomicznych” 2017, nr 27, s. 266-269.

${ }^{40}$ D. Szkopiński, Rola uniwersytetu w rozwoju przedsiębiorczości akademickiej w Polsce na podstawie doświadczeń amerykańskich i zachodnioeuropejskich, „Horyzonty Wychowania” 2016, Vol. 15, nr 35, s. 321.

${ }^{41}$ K. Poznańska, Przedsiębiorczość akademicka - cechy i znaczenie w gospodarce światowej i polskiej [w:] Innowacyjność wspótczesnych organizacji, pod red. T. Kraśnickiej, Katowice 2014, s. 166.

42 J.G. Wissema, Technostarterzy: dlaczego i jak?, PARP, Warszawa 2005, s. 10-12.

${ }^{43}$ K. Poznańska, Przedsiębiorczość akademicka..., s. 165. 
Do najbardziej powszechnych sposobów komercjalizacji wiedzy naukowej i technologii, oprócz udzielania licencji i sprzedaży wynalazku/technologii innemu podmiotowi, zalicza się także uruchamianie działalności gospodarczej przez technostartera w modelu spin-off i spin-out, gdzie ${ }^{44}$ :

- firma spin-off - prowadzi działalność w oparciu o wiedzę i technologie uczelni macierzystej, przez co jest od niej zależna w różnym stopniu,

- firma spin-out - jest całkowicie niezależna od uczelni macierzystej pod względem organizacyjnym, kapitałowym i praw własności.

Niejednokrotnie w literaturze przedmiotu podkreśla się, że przedsiębiorczość akademicka jako swoista twórcza destrukcja przełamuje powszechny stereotyp odnoszący się do klasycznie pojmowanie istoty pracy naukowej55. Praktyka technostarterów pokazuje, że prowadzenie firmy w oparciu o komercjalizację wiedzy może generować liczne korzyści dla technostarterów, uczelni i gospodarki. Nowe firmy technologiczne, powstające z inicjatywy technostarterów, zapewniają szerszy dopływ do gospodarki innowacyjnych rozwiązań, nowe miejsca pracy i rozwój klastrowego łańcucha wartości.

Z raportu Organizacji Współpracy Gospodarczej i Rozwoju (OECD) i Komisji Europejskiej, dotyczącego przedsiębiorczości akademickiej w Polsce wynika, że $\mathrm{e}^{46}$ :

- uczelnie wspierają innowacyjność i angażują się w partnerstwa z otoczeniem gospodarczym, zgodnie z ich strategią rozwoju,

- nauczanie przedsiębiorczości wymaga zwiększenia poziomu interdyscyplinarności,

- relacje uczelni z otoczeniem społeczno-gospodarczym w wielu przypadkach mają charakter personalny, przez co niezbędne jest wzmocnienie instytucjonalnego charakteru relacji z biznesem i lokalnymi samorządami,

- dalsze wsparcie innowacyjności wymaga większych inwestycji ze strony zarówno uczelni, jak i władz publicznych,

- poprawy wymaga internacjonalizacja polskiego szkolnictwa wyższego, przez co wartościowym rozwiązaniem mógłby być nowy program wymiany międzynaro-

${ }^{44}$ K. Chrabąszcz, Przedsiębiorczość akademicka - droga do sukcesu absolwentów uczelni wyższych, „Zeszyty Naukowe Małopolskiej Wyższej szkoły Ekonomicznej w Tarnowie” 2011, t. 18, nr 1, s. 201.

${ }^{45}$ K. Matusiak, M. Matusiak, Pojęcie i ekonomiczne znaczenie przedsiębiorczości akademickiej, „Zeszyty Naukowe Uniwersytetu Szczecińskiego” 2007, nr 453, „Ekonomiczne Problemy Usług", nr 8, s. 160.

46 Raport „Supporting entrepreneurship and innovation in higher education in Poland” powstał w oparciu o wyniki dwuletnich badań (2015-2016). Kwestionariusze ankiety rozesłano do wszystkich polskich szkół wyższych i wybranej grupy studentów. Wywiady indywidualne pogłębione przeprowadzono podczas dwóch wizyt studyjnych w siedmiu polskich uczelniach, tj.: Politechnice Warszawskiej, SGH, Akademii Leona Koźmińskiego, UMCS, Politechnice Gdańskiej, Uniwersytecie Gdańskim oraz PWSZ w Elblągu. Ostatecznie uzyskano 39 wypełnionych ankiet od szkół wyższych i ponad 2 tysiące ankiet od studentów. W trakcie wizyt studyjnych przedstawiciele OECD pozyskiwali informacje także od reprezentantów Konferencji Rektorów Akademickich Szkół Polskich, Narodowego Centrum Badań i Rozwoju, Polskiej Komisji Akredytacyjnej, Polskiej Agencji Rozwoju Przedsiębiorczości, władz lokalnych, akademickich inkubatorów przedsiębiorczości i parków technologicznych. Główne wnioski zawarte w raporcie przedstawiono w Ministerstwie Nauki i Szkolnictwa Wyższego w październiku 2017. Por. http://www. nauka.gov.pl/aktualnosci-ministerstwo/konstytucja-dla-nauki-odpowiada-na-rekomendacje-oecdi-ke.html (dostęp: 1.11.2017 r.). 
dowej pracowników uczelni, który pozwoliłby m.in. wykorzystać doświadczenia zakończonego już programu „Top 500 Innovators” i wspomógłby utrzymanie relacji byłych uczestników programu z zagranicznymi naukowcami.

Bardzo popularnymi współcześnie instytucjami wspierającymi rozwój przedsiębiorczości akademickiej w klastrach są inkubatory przedsiębiorczości o różnych formach prawnych. Ich celem jest zapewnienie odpowiedniego mikroklimatu dla rozwoju początkujących przedsiębiorców akademickich i nieakademickich, w tym udzielanie im potrzebnej i kompleksowej pomocy w wielu wymiarach m.in. finansowym, technicznym i organizacyjnym. W ten sposób mają oni większe szanse na samodzielne przetrwanie na rynku po okresie inkubacji.

Dobrą praktyką w wielu polskich klastrach technologicznych jest promowanie postaw przedsiębiorczych członków i wspieranie rozwoju przedsiębiorczości poprzez tworzenie inkubatorów. Dla przykładu powstały inkubator przedsiębiorczości Tarnowskiego Klastra Przemysłowego zlokalizowany jest w Strefie Aktywności Gospodarczej. Jego przestrzeń dedykowana jest przedsiębiorcom rozpoczynającym działalność gospodarczą lub działającym nie dłużej niż dwa lata. Koordynator klastra zapewnia użytkownikom inkubatora kompleksową opiekę i wsparcie merytoryczne w procesie inwestycyjnym ${ }^{47}$.

Kolejnego dobrego przykładu dostarcza Interizon - Pomorski Klaster ICT. W klastrze współpracują ze sobą lokalne podmioty sektora $\mathrm{B}+\mathrm{R}$, instytucje otoczenia biznesu i firmy związane z informatyką, telekomunikacją, elektroniką, automatyką i robotyką. Do 30 września 2018 roku klaster ma aktywny status Krajowego Klastra Kluczowego nadany przez Ministerstwo Rozwoju w procedurze konkursowej. Status ten oznacza, że klaster cechuje się znaczącym poziomem internacjonalizacji i strategicznym znaczeniem dla rozwoju gospodarki kraju. Aktywność Pomorskiego Klastra ICT - Interizon spójna jest z inteligentną specjalizacją regionalną województwa pomorskiego, dotyczącą technologii interaktywnych w środowisku nasyconym informacyjnie. Regionalna polityka klastrowa realizowana przez Samorząd Województwa Pomorskiego w latach 2007-2013 miała duże znaczenie dla mobilizacji partnerów regionalnych w procesie kształtowania inteligentnych specjalizacji $^{48}$. Należy podkreślić, że w województwie pomorskim po raz pierwszy w Polsce w grudniu 2009 roku dokonano identyfikacji dwóch regionalnych klastrów kluczowych (procedura konkursowa z udziałem ekspertów). Do grupy tej zaliczono wówczas Bałtycki Klaster Ekoenergetyczny i Pomorski Klaster ICT. Z inicjatywy koordynatora i członków klastra Interizon w 2011 roku w Gdańskim Parku Naukowo-Technologicznym powstał inkubator przedsiębiorczości. Jego celem jest stworzenie jak najkorzystniejszych warunków rozwoju dla młodych przedsiębiorstw z branży ICT na Pomorzu, będących członkami klastra. Zakres działalności użytkowników przestrzeni inkubatora dotyczy projektowania i wdrażania innowacji technologicznych typu: technologie systemów informatycznych i sieci telekomunikacyjnych, technologie zarządzania informacją i inne technologie ICT. Tego typu działanie jest spójne z misją klastra. Jej deklaracja zakłada, że stwarza on szczególnie korzystne warunki do rozwoju firm branży ICT w regionie poprzez dostarczanie wiedzy, wspieranie innowacyjności, stymulowanie współpracy biznesu i nauki oraz realizowanie wspólnych celów swoich członków ${ }^{49}$. Funkcję administratora klastra pełni od 2009 roku Wydział Elektroniki, Telekomunikacji i Informatyki Politech-

\footnotetext{
${ }^{47}$ http://www.tkp.com.pl/oferta-inwestycyjna/inkubator-przedsiebiorczosci (dostęp: 7.11.2017 r.).

48 https://drg.pomorskie.eu/pomorskie-klastry-w-obszarach-isp (dostęp: 7.11.2017 r.).

${ }^{49} \mathrm{http} / / /$ interizon.pl (dostęp: 11.11.2017 r.).
} 
niki Gdańskiej. Partnerzy w klastrze uznali bowiem, że jest to odpowiedni podmiot, który posiada nie tylko wysokie kompetencje, ale także silną pozycję i neutralność niezbędną dla sprawnego organizowania wspólnych działań w klastrze. Proces komercjalizacji wyników badań w Politechnice Gdańskiej odbywa się poprzez Centrum Transferu Wiedzy i Technologii oraz spółkę celową Excento, w której uczelnia posiada 100\% udziałów. Najbardziej popularnymi formami tej komercjalizacji są: udzielanie przedsiębiorstwom licencji na korzystanie z wyników badań oraz tworzenie firm spin-off na podstawie uzyskanych wyników badań. W przypadku komercjalizacji wynalazku lub rozwiązania innowacyjnego przez Politechnikę Gdańską, twórcom przysługuje 50\% zysku z komercjalizacji. Efektem przedsiębiorczości akademickiej w Politechnice Gdańskiej są dynamicznie powstające spółki typu spin-off z udziałem kapitałowym uczelni, m.in..$^{50}$ :

- NovaPUR - spółka prowadząca działalność B+R w oparciu o technologię produkcji ekologicznych sztywnych pianek poliuretanowych i sprzedaż licencji na tego typu rozwiązanie technologiczne, znajdujące zastosowanie w przemyśle lotniczym, motoryzacyjnym, odzieżowym i budownictwie;

- CHILLID - spółka utworzona w oparciu o technologię, pozwalającą na zbudowanie taniej i łatwej w zastosowaniu inteligentnej etykiety w postaci identyfikatora, która informuje o jakości i długości życia produktu;

- ARGEVIDE - spółka zajmująca się wdrożeniem i sprzedażą usług opracowanych w ramach projektu NOR-STA, oferowanych przez Internet, zorientowana jest na wspieranie efektywnego zarządzania jakością (procesów osiągania, oceny i utrzymania zgodności z normami i standardami) poprzez stosowanie narzędzi informatycznych w pracy m.in. konsultantów, audytorów i jednostek certyfikujących;

- AssisTech - spółka skoncentrowana na opracowywaniu i komercjalizacji innowacyjnych rozwiązań z obszaru informatyki, multimediów i inżynierii biomedycznej;

- Detoxed Home - spółka stworzona przez pracowników naukowych Politechniki Gdańskiej i Gdańskiego Uniwersytetu Medycznego, aby wpierw opracować nowatorską metodę zmniejszania narażania na związki endokrynnie czynne (EDC) w warunkach domowych, a później ją skomercjalizować;

- Solutions 4 Tomorrow - spółka, której celem strategicznym jest rozwijanie bezzałogowych statków powietrznych w kierunku ich całkowitej autonomizacji, poprawy wydajności i bezpieczeństwa.

Poszczególne jednostki Politechniki Gdańskiej w różnym stopniu współpracują z przedsiębiorcami w ramach nie tylko Pomorskiego Klastra ICT - Interizon, ale także w: Klastrze KlimaPomerania, Gdańskim Klastrze Budowlanym, Bałtyckim Klastrze Ekoenergetycznym, Polskim Klastrze Morskim oraz Pomorskim Klastrze BioEcoChem ${ }^{51}$.

Większość klastrów wysokich technologii w Polsce funkcjonuje w sposób zbliżony do holenderskiego modelu klastra, w którym podmioty sektora $\mathrm{B}+\mathrm{R}$ pełnią bezpośrednią lub pośrednią rolę w zarządzaniu rozwojem klastra. Bezpośrednia rola sprowadza się do pełnienia funkcji koordynatora klastra, a pośrednia - zwykle polega na aktywnym wspieraniu menedżera klastra w realizowaniu funkcji brokera innowacji. Główne zadania brokera innowacji jako pośrednika między przedsiębiorcami i naukowcami, integratora procesu innowacyjnego i animatora współpracy klastrowej, dotyczą zarządzania wiedzą klastra,

\footnotetext{
${ }^{50} \mathrm{https} / / /$ pg.edu.pl/spolki-spin-off (dostęp: 11.11.2017 r.).

${ }^{51}$ https://ctwt.pg.edu.pl/klastry (dostęp: 11.11.2017 r.).
} 
identyfikowania potrzeb liderów technologicznych, wspierania aktywnych naukowców w realizacji i komercjalizacji swoich prac B+R we współpracy z biznesem i kształtowania w klastrze klimatu sprzyjającego przedsiębiorczości i innowacyjności. Niezmiernie ważna jest także jego aktywność w budowaniu marki klastra zaawansowanego technologicznie. Sprawna komunikacja marketingowa klastra stanowi swoisty sygnał dla przedstawicieli zagranicznych środowisk naukowo-technologicznych oraz talentów i młodych firm innowacyjnych, często powstałych w ramach przedsiębiorczości akademickiej, aby włączyć się w szerszym zakresie we współpracę klastrową, obserwatorium technologiczne, rozwój kapitału ludzkiego i transfer wiedzy ${ }^{52}$.

\section{ROLA KLASTRÓW WYSOKICH TECHNOLOGII W KSZTAŁTOWANIU INTELIGENTNYCH MIAST I REGIONÓW UCZĄCYCH SIĘ}

Aktywność klastrów wysokich technologii, w tym klastrów technologii informacyjnokomunikacyjnych (ICT), ma strategiczne znaczenie dla długofalowego procesu przemian miast i regionów. Uwzględnienie wymiaru zarówno technologicznego, jak i społecznego w ramach zrównoważonego rozwoju miast i regionów jest odpowiedzią na zmiany w zakresie polityki spójności, polityki regionalnej i współczesnych procesów urbanizacji.

Koncepcja inteligentnego miasta (smart city) odnosi się do rozwoju ośrodków miejskich poprzez zastosowanie nowych rozwiązań w wielu dziedzinach ich funkcjonowania, aby możliwe było sprawne wykorzystanie zasobów wiedzy i innowacji dla poprawy efektywności i konkurencyjności gospodarki ${ }^{53}$. Wskazuje na potrzebę myślenia strategicznego i kompleksowego podejścia w zarządzaniu rozwojem miasta. Jej implementacja nie zawsze wiąże się z koniecznością ponoszenia wysokich kosztów. Wymaga przede wszystkim pozytywnych zmian organizacyjnych i odważnych decyzji władz miasta ${ }^{54}$.

W literaturze przedmiotu nie sposób nie zauważyć wielości podejść w zakresie definiowania inteligentnego miasta. Najczęściej ujmowane jest ono jako miasto, które ${ }^{55}$ :

- podejmuje inwestycje w kapitał społeczny oraz infrastrukturę w celu aktywnego promowania zrównoważonego rozwoju i wysokiej jakości życia, w tym racjonalnego gospodarowania zasobami naturalnymi,

- wykorzystuje w różnym stopniu technologie informacyjno-komunikacyjne w celu zwiększenia interaktywności i wydajności infrastruktury miejskiej i jej podstawowych komponentów,

52 Obserwatorium technologiczne tworzy zespół specjalistów klastra, którzy na bieżąco analizują rozwój innowacyjnych technologii w przestrzeni międzynarodowej, istotnych z punktu widzenia aktywności członków klastra. Opracowane przez nich raporty i rekomendacje mogą pozwolić członkom klastra na sprawne wykorzystanie szans, jakie stwarza turbulentne otoczenie. Por. L. Palmen, M. Baron, Przewodnik dla animatorów inicjatyw klastrowych w Polsce, PARP, Warszawa 2016, s. 206-208.

53 A. Nowakowska, Budowanie inteligentnego miasta. Studium przypadku Montpellier, „Studia Miejskie" 2015, t. 19, s. 24.

${ }^{54}$ M. Jankowska, Smart city jako koncepcja zrównoważonego rozwoju miasta - przykład Wiednia, „Studia i Prace Wydziału Nauk Ekonomicznych i Zarządzania” nr 42, t. 2, s. 180.

55 M. Czupich, A. Ignasiak-Szulc, M. Kola-Bezka, Czynniki i bariery wdrażania koncepcji smart city w Polsce, ,Studia Ekonomiczne - Zeszyty Naukowe Uniwersytetu Ekonomicznego w Katowicach" 2016, nr 276, s. 224-225. 
- rozwiązuje kwestie publiczne $\mathrm{z}$ wykorzystaniem nowych technologii informacyjno-komunikacyjnych przy zaangażowaniu różnych interesariuszy, działających w partnerstwie terytorialnym,

- oparte jest na kapitale ludzkim i społecznym oraz nowych technologiach,

- charakteryzuje się inteligentnym zarządzaniem publicznym, innowacyjną i konkurencyjną gospodarką, zrównoważonym wykorzystaniem zasobów, rozwiniętym kapitałem społecznym i wysoką jakością życia w bezpiecznej przestrzeni.

Według A. Zakrzewskiej-Półtorak inteligentne miasta stymulują i przyciągają kreatywnych ludzi, przedsiębiorcze organizacje, innowacyjne projekty. Jednakże, aby inteligentne miasto lub miasta mogły stać się katalizatorem rozwoju regionu ich zakorzenienia, muszą $\mathrm{w}$ ich przestrzeni występować silne i liczne powiązania funkcjonalne poziome i pionowe oraz odpowiedni poziom kapitału ludzkiego i społecznego ${ }^{56}$.

Dobrego przykładu wpływu klastrów wysokich technologii na rozwój inteligentnych miast dostarcza Klaster Smart IT. Jego struktura ukonstytuowała się w celu wzmocnienia współpracy pomiędzy podmiotami działającymi w obszarze innowacyjnych technologii, promowania i rozpowszechniania rozwiązań informatycznych członków klastra. Klaster koncentruje się m.in. na wykorzystaniu odnawialnych źródeł energii, promowaniu idei inteligentnego miasta i wdrażaniu technologii, które mogą poprawić jakość życia na jego terytorium. Członkowie klastra zakładają, że tworzona przez nich inteligenta sieć zarządzania energią wpływa na poprawę konkurencyjności rynku energetycznego i efektywności użytkowania energii elektrycznej. Ich priorytetowymi programami, które mogą służyć rozwojowi inteligentnego miasta, są Smart Grid - inteligentne sieci elektroenergetyczne i Smart Metering - inteligentne systemy pomiarowe ${ }^{57}$.

Inteligentne miasta i klastry wysokich technologii mogą stać się katalizatorem rozwoju regionu uczącego się (learning region). Świadczą o tym chociażby założenia terytorialnych modeli innowacji i koncepcja polaryzacyjno-dyfuzyjna rozwoju regionó $w^{58}$.

Koncepcja regionu uczącego się odnosi się do rozwoju regionu w oparciu o transfer wiedzy, dyfuzję innowacji, kształtowanie kapitału przedsiębiorczości i skłonność mieszkańców regionu do podejmowania działalności gospodarczej ${ }^{59}$. Względnie trwałym źródłem przewagi konkurencyjnej regionu jest sprawne zarządzanie kapitałem intelektualnym, w tym wiedzą. W kształtowaniu konkurencyjności regionu niezmiernie ważne jest zatem zapewnienie odpowiednich warunków dla ciągłego rozwoju wiedzy przez kluczowych aktorów regionalnej gospodarki. Region uczący się jako fundament gospodarki napędzanej przez wiedzę opiera się na pięciu podstawowych elementach ${ }^{60}$ :

- infrastrukturze produkcyjnej, wykorzystującej outsourcing i sprzyjającej rozwojowi sieci poddostawców,

- infrastrukturze rynku pracy, która determinowana jest dostępnością pracowników wiedzy, zdolnych do ciągłego doskonalenia i ustawicznego uczenia,

\footnotetext{
56 A. Zakrzewska-Półtorak, Inteligentne miasto katalizatorem rozwoju regionu?, „Prace Naukowe Uniwersytetu Ekonomicznego we Wrocławiu” 2016, nr 443, s. 283.

57 http://smartpl.org/ (dostęp: 1.10.2017 r.).

58 A. Zakrzewska-Półtorak, Inteligentne miasto..., s. 288.

59 M. Godowska, Region uczacy się - uwarunkowania i determinanty rozwoju na przykładzie województwa małopolskiego, „Przedsiębiorczość - Edukacja” 2012, nr 8, s. 281-284.

${ }^{60}$ R. Florida, Toward the learning region, „Futures” 1995, Vol. 27, nr 5, s. 532-534.
} 
- infrastrukturze komunikacyjnej, która umożliwia mobilność ludzi, transfer informacji, wyrobów i usług w przestrzeni krajowej i międzynarodowej,

- infrastrukturze rynku finansowego, która umożliwia sprawny przepływ kapitału w gospodarce, aby pobudzać rozwój wiedzy i innowacji,

- polityce przemysłowej, która uwzględnia potrzeby partnerów biznesowych i społecznych w efektywnym wykorzystaniu zasobów, stymulowaniu zmian strukturalnych w przemyśle i kształtowaniu jego konkurencyjności.

Region uczący się tworzą indywidualni ludzie i organizacje, będąc czynnie zaangażowanymi we współpracę i związane $\mathrm{z}$ nią procesy wymiany wiedzy, technologii i pomysłów. Koncentracja danego regionu na intensywnym wykorzystaniu i rozwijaniu wiedzy poprzez różne formy współpracy m.in. klastry zaawansowane technologicznie, zapewnia powstawanie efektów synergii w procesie interaktywnego, instytucjonalnego i organizacyjnego uczenia się ${ }^{61}$. Zachodzące $w$ klastrach zbiorowe procesy uczenia się, które generują innowacje, jednocześnie zwiększają konkurencyjność ich członków ${ }^{62}$.

Konkludując, należy podkreślić, że koncepcje inteligentnego miasta i regionu uczącego się są komplementarne wobec siebie. Z jednej strony wymagają odpowiedniej infrastruktury wspierającej tworzenie i przepływ wiedzy, a z drugiej stymulują innowacyjność i przedsiębiorczość, przekształcanie zasobów materialnych i niematerialnych w wyroby i usługi ekonomicznie i społecznie użyteczne. Ich pomyślna implementacja determinowana jest współcześnie w znacznej mierze koniecznością uwzględnienia regionalnych inteligentnych specjalizacji, odnoszących się do specyfiki i unikatowości danego regionu, kreatywnego środowiska, produkcji wiedzy i komercjalizacji wyników badań naukowych.

\section{ZAKOŃCZENIE}

$\mathrm{W}$ procesie formułowania koncepcji inteligentnej specjalizacji, jej popularyzacji i wdrażania niejednokrotnie wykazywano, że przedsiębiorczość i innowacyjność klastrów wysokich technologii ma strategiczne znaczenie dla długofalowego procesu przemian dokonujących się $\mathrm{w}$ gospodarce. Wynika to $\mathrm{z}$ faktu, że potencjał strategiczny tej grupy klastrów powstaje na fundamencie ścisłej współpracy przedsiębiorstw zaawansowanych technologicznie $\mathrm{z}$ różnymi podmiotami sektora $\mathrm{B}+\mathrm{R}$ i innymi partnerami $\mathrm{w}$ ramach procesu innowacyjnego, zorientowanego na nowe technologie, rozwój wiedzy oraz komercjalizację osiągnięć naukowych. Naturalne jest zatem, że aktywność klastrów wysokich technologii w wielu regionach Polski była źródłem inteligentnej specjalizacji.

Klastry wysokich technologii często funkcjonują zgodnie $\mathrm{z}$ holenderskim modelem rozwoju klastra. W tym modelu podmioty sektora $\mathrm{B}+\mathrm{R}$ pełnią bezpośrednio funkcję koordynatora klastra lub wspierają menedżera klastra w pełnieniu funkcji brokera innowacji. Od sprawności zarządzania klastrem wysokich technologii w warunkach turbulentnego otoczenia zależy m.in. to jak szybko klaster będzie rozwijał się i generował oczekiwane efekty klastrowej synergii. Biorąc pod uwagę korzyści jakie mogą powstać w środowisku tego typu klastrów, tym bardziej zasadne jest takie ukształtowanie polityki klastrowej na poziomie centralnym i regionalnym, aby klastry te $\mathrm{z}$ jednej strony otrzymały publiczne

${ }^{61}$ D. Czyżewska, Konkurencyjność regionu uczacego się - ujęcie konceptualne, „Prace Naukowe Uniwersytetu Ekonomicznego we Wrocławiu" 2013, nr 285, s. 21-22.

${ }^{62}$ B. Mikołajczyk, A. Kurczewska, J. Fila, Klastry na świecie. Studia przypadków, Warszawa 2009, s. 25 . 
wsparcie, adekwatne do swoich potrzeb, a z drugiej, aby sprawnie wykorzystywano je jako kluczowe narzędzie w polityce regionalnej, przemysłowej i innowacyjnej.

Rozważania przedstawione w artykule są szczególnie aktualne współcześnie, zważywszy chociażby na wciąż trwającą transformację szkolnictwa wyższego w Polsce w warunkach gospodarki opartej na wiedzy i związanej z nią sieciowości, która coraz silniej przenika różne płaszczyzny życia społeczno-gospodarczego. Zachodzące zmiany mają z założenia $\mathrm{z}$ jednej strony poprawić jakość w zakresie działalności dydaktycznej i naukowej uczelni wyższych, a z drugiej wzmocnić ich relacje z interesariuszami w ramach modelu przedsiębiorczej uczelni (uczelni III generacji). Obserwowalne coraz szersze otwarcie coraz większej grupy uczelni w Polsce na partnerów klastrowych przejawia się najczęściej w uwzględnianiu ich potrzeb we współpracy klastrowej, w działalności dydaktyczno-naukowej, przyśpieszaniu transferu wiedzy i technologii w różnych formach. Stopniowo wdrażany model uczelni przedsiębiorczej, pożądany przez gospodarkę i władze publiczne, może stymulować przedsiębiorczość akademicką oraz przyśpieszyć tworzenie i dyfuzję innowacji, zwłaszcza tych przełomowych. Z pewnością, większa aktywność uczelni w środowisku klastrów wysokich technologii będzie sprzyjała likwidacji licznych barier przedsiębiorczości akademickiej o mentalnym, kompetencyjnym, instytucjonalnym, biurokratyczno-administracyjnym, informacyjnym i organizacyjno-finansowym charakterze.

$\mathrm{Z}$ przeprowadzonej analizy literatury przedmiotu wynika, że przedsiębiorczość akademicka poprzez wzmocnienie ekosystemu klastra może przyczynić się do urzeczywistnienia koncepcji inteligentnych miast i regionów uczących się. Naturalna integracja nauki z biznesem jako atrybut tej formy przedsiębiorczości, przejawiająca się w komercjalizacji wiedzy naukowej i upowszechnieniu technologii $\mathrm{w}$ przestrzeni miast i regionów może stymulować sprawność zarządzania tymi jednostkami, optymalne wykorzystanie posiadanych przez nie zasobów w zgodzie z ideą zrównoważonego rozwoju oraz poprawę jakości życia. Dzięki temu miasta i regiony mogą stawać się coraz bardziej innowacyjne i ekologiczne, a przez to coraz bardziej atrakcyjne nie tylko dla mieszkańców, ale także dla pracowników wiedzy (knowledge workers), przedsiębiorców i inwestorów.

Przedsiębiorczość akademicka w klastrach wysokich technologii to wciąż nowy obszar badań, słabo ugruntowany w polskiej literaturze naukowej. Tym samym w artykule podjęto się próby syntetycznej ilustracji uzyskanych wyników badań. Nie wyczerpano jednakże wszystkich zagadnień związanych $\mathrm{z}$ analizowanym problemem badawczym. Możliwe kierunki dalszych badań empirycznych na gruncie nauk o zarządzaniu to m.in. identyfikacja pozytywnych i negatywnych doświadczeń w zakresie przedsiębiorczości akademickiej w klastrach wysokich technologii, rozpoznanie jej kluczowych barier w przestrzeni krajowej i zagranicznej oraz analiza klastrowych startupów. Z uwagi, że przedstawione wyniki badań i wnioski odnoszą się przede wszystkim do specyfiki klastrów zaawansowanych technologicznie, tym bardziej istotne jest szczegółowe rozpoznanie, który rodzaj klastra, z uwzględnieniem jego branży, fazy życia, zakresu terytorialnego, modelu rozwoju, najbardziej sprzyja rozwojowi przedsiębiorczości akademickiej, a który najmniej.

\section{Literatura}

[1] Adamik A., Zakrzewska-Bielawska A., Rozwój przedsiębiorstw high-tech [w:] Koopetycja w rozwoju przedsiębiorstw high-tech, red. A. Zakrzewska-Bielawska, Wydawnictwo Placet, Warszawa 2014. 
[2] Baran A., Prawne aspekty innowacyjności w kontekście kluczowych technologii wspomagajacych, „Zeszyty Naukowe Politechniki Śląskiej. Organizacja i Zarządzanie” 2014, $\mathrm{nr} 71$.

[3] Baranowska A., Gąska J., Lis M., Pelle D., Skrok Ł., Klastry zaawansowanych technologii jako instrument wsparcia rozwoju i konkurencyjności regionów - analiza $i$ wnioski dla polityki regionalnej oraz polityki spójności, Instytut Badań Strukturalnych, Warszawa 2009.

[4] Bresnahan T., Gambardella A., Building high-tech clusters: Silicon Valley and beyond, Cambridge University Press, Cambridge 2004.

[5] Buczyńska G., Frączek D., Kryjom P., Raport z inwentaryzacji klastrów w Polsce - 2015, PARP, Warszawa 2016.

[6] Chrabąszcz K., Przedsiębiorczość akademicka - droga do sukcesu absolwentów uczelni wyższych, „Zeszyty Naukowe Małopolskiej Wyższej szkoły Ekonomicznej w Tarnowie” 2011, t. 18, nr 1.

[7] Czupich M., Ignasiak-Szulc A., Kola-Bezka M., Czynniki i bariery wdrażania koncepcji smart city w Polsce, „Studia Ekonomiczne - Zeszyty Naukowe Uniwersytetu Ekonomicznego w Katowicach” 2016, nr 276.

[8] Czyżewska D., Konkurencyjność regionu uczacego się - ujęcie konceptualne, „Prace Naukowe Uniwersytetu Ekonomicznego we Wrocławiu" 2013, nr 285.

[9] Daszkiewicz N., Internacjonalizacja przedsiębiorstw z branż high-tech, „Problemy Zarządzania" 2015, Vol. 13, nr 4 (56).

[10] Dziedzic S., Woźniak L., Czerepiuk P., Proces przedsiębiorczego odkrywania jako metoda strategicznego planowania i implementacji inteligentnych specjalizacji regionu, „Prace Naukowe Uniwersytetu Ekonomicznego we Wrocławiu” 2016, nr 444.

[11] Dzierżanowski M., Definiowanie i rozwijanie inteligentnych specjalizacji, Instytut Badań nad Gospodarką Rynkową, Gdańsk 2013.

[12] Florida R., Toward the learning region, „Futures” 1995, Vol. 27, nr 5.

[13] Godlewska S., Strategie na rzecz inteligentnej specjalizacji (RIS3): instrument realizacji polityki rozwoju vs. warunek pozyskiwania funduszy unijnych, „Przegląd Europejski” 2013, nr 4 (30).

[14] Godowska M., Region uczacy się - uwarunkowania i determinanty rozwoju na przykładzie województwa małopolskiego, „Przedsiębiorczość - Edukacja” 2012, nr 8.

[15] Grądziel A., Strategia inteligentnej specjalizacji stymulatorem rozwoju gospodarczego regionów, „Studia i Prace Wydziału Nauk Ekonomicznych i Zarządzania” 2014, nr 37, t. 2.

[16] Gurba K., Rola uczelni wyższych w klastrach wysokich technologii, „Zarządzanie i Finanse” 2012, nr 1 .

[17] http://interizon.pl/ (dostęp: 11.11.2017 r.).

[18] http://nanoslask.pl/index.php/pl/inicjatorzy-klastra/uniwersytet-slaski (dostęp: 1.10.2017 r.)

[19] http://przemysl-40.pl/ (dostęp: 1.11.2017 r.).

[20] http://smartpl.org/ (dostęp: 1.10.2017 r.).

[21] http://www.dolinalotnicza.pl (dostęp: 1.09.2017 r.).

[22] http://www.nauka.gov.pl/aktualnosci-ministerstwo/konstytucja-dla-nauki-odpowiada-narekomendacje-oecd-i-ke.html (dostęp: 1.11.2017 r.).

[23] http://www.pi.gov.pl/parp/chapter_86197 (dostęp: 1.10.2017 r.). 
[24] http://www.tkp.com.pl/oferta-inwestycyjna/inkubator-przedsiebiorczosci (dostęp: 7.11. 2017 r.).

[25] http://www.transfer.us.edu.pl/firmy-na-uniwersytecie-slaskim (dostęp: 1.11.2017 r.).

[26] https://ctwt.pg.edu.pl/klastry (dostęp: 11.11.2017 r.).

[27] https://drg.pomorskie.eu/pomorskie-klastry-w-obszarach-isp (dostęp: 7.11.2017 r.).

[28] Jankowska M., Smart city jako koncepcja zrównoważonego rozwoju miasta - przykład Wiednia, ,Studia i Prace Wydziału Nauk Ekonomicznych i Zarządzania” nr 42, t. 2.

[29] Łasak P., Rola rodzimych korporacji wielonarodowych $w$ rozwoju przemystu wysokich technologii na rynkach wschodzacych, ,Studia Ekonomiczne - Zeszyty Naukowe Uniwersytetu Ekonomicznego w Katowicach” 2016, nr 271.

[30] Matusiak K., Matusiak M., Pojęcie i ekonomiczne znaczenie przedsiębiorczości akademickiej, „Zeszyty Naukowe Uniwersytetu Szczecińskiego” 2007, nr 453, „Ekonomiczne Problemy Usług”, nr 8.

[31] Mempel-Śnieżyk A., Koncepcje rozwoju regionalnego ze szczególnym uwzględnieniem klastrów i inteligentnych specjalizacji, „Biblioteka Regionalisty” 2013, nr 13.

[32] Mikołajczyk B., Kurczewska A., Fila J. Klastry na świecie, Difin, Warszawa 2009.

[33] Nowakowska A., Budowanie inteligentnego miasta. Studium przypadku Montpellier, „Studia Miejskie” 2015, t. 19.

[34] Olearnik J., Pluta-Olearnik M., Uniwersytet przedsiębiorczy - herezja czy nowa orientacja na uczelni?, „Horyzonty Wychowania” 2016, Vol. 15, nr 35.

[35] Palmen L., Baron M., Przewodnik dla animatorów inicjatyw klastrowych w Polsce, PARP, Warszawa 2016.

[36] PARP, Raport o stanie sektora matych i średnich przedsiębiorstw w Polsce, PARP, Warszawa 2017.

[37] Piasecka A., Przedsiębiorcza uczelnia jako wspótczesny model szkoły wyższej, „Zeszyty Naukowe Uniwersytetu Szczecińskiego” 2012, nr 725, „Ekonomiczne Problemy Usług”, nr 98.

[38] Poznańska K., Przedsiębiorczość akademicka - cechy i znaczenie w gospodarce światowej i polskiej [w:] Innowacyjność współczesnych organizacji, red. T. Kraśnicka, Wyd. Uniwersytetu Ekonomicznego w Katowicach, Katowice 2014.

[39] Ratajczak-Mrozek M., Proces umiędzynarodowienia a wspótpraca przedsiębiorstw hightech z podmiotami zagranicznymi, „Gospodarka Narodowa” 2013, nr 1-2.

[40] Ratajczak-Mrozek M., Specyfika przedsiębiorstw zaawansowanych technologii (hightech), „Przegląd Organizacji” 2011, nr 2.

[41] Regionalna Strategia Innowacji Województwa Podkarpackiego na lata 2014-2020 na rzecz inteligentnej specjalizacji, Urząd Marszałkowski Województwa Podkarpackiego, Rzeszów 2016.

[42] Runiewicz-Wardyn M., Dynamika przemystów wysokich technologii a rozwój klastrów wiedzy na przyktadzie klastra Route 128, ,Master of Business Administration” 2011, nr 4 (114).

[43] Skawińska E., Zalewski R., Klastry biznesowe w rozwoju konkurencyjności i innowacyjności regionów, PWE, Warszawa 2009.

[44] Skórska A., Sektor high-tech jako czynnik wzrostu konkurencyjności polskiej gospodarki w perspektywie 2020 roku, ,Zarządzanie i Finanse” 2016, Vol. 14, nr 3.

[45] Słodowa-Hełpa M., Inteligentna specjalizacja polskich regionów: warunki, wyzwania i dylematy, „Roczniki Nauk Społecznych” 2013, t. 5 (41), nr 1. 
[46] Sułkowski Ł., Seliga R., Przedsiębiorczy uniwersytet - zastosowanie zarządzania strategicznego, „Prace Naukowe Uniwersytetu Ekonomicznego we Wrocławiu” 2016, nr 444.

[47] Szkopiński D., Rola uniwersytetu w rozwoju przedsiębiorczości akademickiej w Polsce na podstawie doświadczeń amerykańskich i zachodnioeuropejskich, „Horyzonty Wychowania" 2016, Vol. 15, nr 35.

[48] Szmigiel J., Klastry jako instrument wsparcia sektora kluczowych technologii wspomagajacych, „Handel Wewnętrzny” 2016, nr 6 (365).

[49] Szostak E., Inteligentne specjalizacje w rozwoju regionu, „Studia Ekonomiczne” 2015, nr 209.

[50] Wissema J.G., Technostarterzy: dlaczego i jak?, PARP, Warszawa 2005.

[51] Zakrzewska-Bielawska A., Potencjat relacyjny a innowacyjność przedsiębiorstwa $w$ kierunku open innovation, „Management Forum” 2016, Vol. 4, nr 1.

[52] Zakrzewska-Bielawska A., Relacje między strategia a struktura organizacyjna $w$ przedsiębiorstwach sektora wysokich technologii, Wydawnictwo Politechniki Łódzkiej, Łódź 2011.

[53] Zakrzewska-Bielawska A., Rola koopetycji w podnoszeniu konkurencyjności przedsiębiorstw - benchmarki dziatań koopetycyjnych w praktyce firm high-tech, ,Prace Naukowe Uniwersytetu Ekonomicznego we Wrocławiu” 2014, nr 363.

[54] Zakrzewska-Bielawska A., Strategie wzrostu przedsiębiorstw sektora wysokich technologii w ujęciu empirycznym, „Prace Naukowe Uniwersytetu Ekonomicznego we Wrocławiu" 2011, nr 219.

[55] Zakrzewska-Półtorak A., Inteligentne miasto katalizatorem rozwoju regionu?, „Prace Naukowe Uniwersytetu Ekonomicznego we Wrocławiu” 2016, nr 443.

[56] Ziółkowski B., Jankowska-Mihułowicz M., Chudy-Laskowska K., Piecuch T., Uwarunkowania konkurencyjności przedsiębiorstw stosujących systemy RFID z API - wyniki badań metoda delficka, ,Przegląd Nauk Ekonomicznych” 2017, nr 27.

[57] Ziółkowski B., Piecuch T., Jankowska-Mihułowicz M., Chudy-Laskowska K., Rozwój systemów RFID w przedsiębiorstwach. Wyniki badań metodą delficka, Oficyna Wydawnicza Politechniki Rzeszowskiej, Rzeszów 2016.

\section{ACADEMIC ENTREPRENEURSHIP WITHIN HIGH-TECH CLUSTERS AS AN INDICATOR OF SMART SPECIALISATION}

The subject of this cognitive-synthetic article is contemporary issues regarding the development of academic entrepreneurship in high-tech clusters, whose activity is consistent with the main assumptions of the smart specialisation concept. Scientific considerations and conclusions made within this paper are based on literature review and desk research. The practical approach to the subject under discussion is followed by numerous examples of Polish clustering. The article consists of four parts. They synthetically depict the characteristics of smart specialisation, strategic dimension of high-tech clusters and academic entrepreneurship, the main assumptions of the concept of smart city and learning region. As the concept of smart specialisation refers to region identity and efficient use of its scientific, technological, social, and economic potential, an attempt was made to prove a conceptual relationship between this concept and high-tech clusters activity, academic entrepreneurship, and smart cities and learning regions. The high tech clusters are treated as intelligent organisations still forming conducive ecosystem for development of academic entrepreneurship, smart cities and learning regions. It favors gradually counteracts barriers 
to entrepreneurship, facilitates commercialisation of scientific research results, optimal use of strategic potential of technical universities cooperating with high technology companies, and the transfer of broadly-understood knowledge. The scope and quality of the support for technostarters offered in the cluster, in achieving their business maturity, shape the positive image of the cluster.

Keywords: cluster, technology, academic entrepreneurship, smart specialisation

DOI: $10.7862 / \mathrm{rz} .2017 . \mathrm{mmr} .38$

Tekst złożono do redakcji: grudzień 2017 r.

Tekst przyjęto do druku: styczeń $2018 \mathrm{r}$. 